\title{
COVID-19 Pandemisi Sürecinde Yetișkinlerin Besin Destekleri Kullanımlarının İncelenmesi
}

\section{Investigation of Adults' Use of Dietary Supplements during the COVID-19 Pandemic}

\author{
iD Gülperi Demir ${ }^{1}$ iD Beyza Kılıçkalkan², ${ }^{2}$ Muhammed Kazım Takak ${ }^{2}$
}

${ }^{1}$ Selçuk Üniversitesi, Sağlık Bilimleri Fakültesi, Beslenme ve Diyetetik Bölümü, Konya, TÜRKIYYE

${ }^{2}$ Selçuk Üniversitesi, Sağlık Bilimleri Enstitüsü, Beslenme ve Diyetetik Ana Bilim Dalı, Konya, TÜRKIYE

$\ddot{\mathbf{O z}}$

Amaç: Bu araştırmanın amacı, COVID-19 pandemi sürecinde yetişkinlerin besin destekleri (vitamin-mineral ve bitkisel ürün) kullanımlarının incelenmesidir

Gereç ve Yöntem: Tanımlayıcı ve kesitsel nitelikte olan araștırma, Mayıs 2021-Ağustos 2021 tarihleri arasında gerçekleștirilmiștir. Çalıșma 18-65 yaș arası 402 yetișkin üzerinde yürütülmüştür. Veri toplama aracı olarak online anket formu uygulanmıştır.

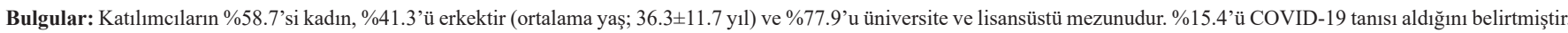
Katılımcıların \%66.2'si pandemi sürecinde besin destekleri kullanmıştır. Besin destekleri kullanım amaçları sırasıyla; 'bağışıklık sistemini güçlendirmek' (\%72.9), 'kendini iyi hissetmek' (\%44.0), ‘COVID-19’dan korunmak’ (\%39.1) ve 'vücuttaki yetersizliği gidermek'(\%35.7) tir. Katılımcıların yarıdan fazlasının besin desteklerinin COVID-19'a karşı koruyucu olduğuna inandığı ve COVID-19 tanısı olanların çoğunluğunun (\%80.6) besin destekleri kullanmaya başladıkları saptanmıştır. Katılımcıların besin desteği hakkında bilgiyi en çok kitle iletişim araçlarından edindikleri; besin desteği kullanma kararında sağlık uzmanlarının, kitle iletişim araçlarının ve sosyal çevrenin etkili olduğu belirlenmiş̧tir. Pandemi sürecinde en çok kullanılan besin destekleri C, D, B grubu vitaminleri, zencefil, tarçın, yeşil çay ve zerdeçaldır. Çalışmada, besin destekleri kullanımında; cinsiyet, öğrenim durumu ve yaşanılan yer, medeni durum, gelir, meslek, kronik hastalık durumu, COVID-19 tanısı olma durumunun etkili olduğu saptanmıştır.

Sonuç: Araştırmanın sonucunda, COVID-19 pandemi sürecinde yetişkinlerin besin destekleri kullanımının arttığı ortaya çıkmıştır. Besin destekleri, beslenmeyi destekleyici veya bağışıklığı güçlendirici olarak kullanılmasıyla birlikte yanlış bilgiler ve bilinçsiz kullanım sonunda sağlığı bozucu etkiler de ortaya çıkarmaktadır. Bu nedenle, besin desteklerinin doktor veya diyetisyen gibi uzmanların kontrolünde kullanılması ve sağlığa etkileri konusunda farkındalığın artırılması önemlidir.

Anahtar Kelimeler; Besin destekleri, Covid-19, pandemi, bağışıklık, sağlık

Abstract

Objective: The aim of this study is to examine the use of dietary supplements (vitamin-mineral and herbal products) by adults during the COVID-19 pandemic.

Materials and Methods: The descriptive and cross-sectional study was performed between May 2021 and August 2021. The study was conducted on 402 adults aged between 18-65 years old. An online questionnaire was used as a data collection tool.

Results: $58.7 \%$ of the participants were female, $41.3 \%$ male (mean age; $36.3 \pm 11.7$ years), and $77.9 \%$ of them were university or postgraduate degrees. $15.4 \%$ stated that they were diagnosed with COVID-19. 66.2\% of the participants used dietary supplements during the pandemic. Participants'purposes for using nutritional supplements were to 'strengthen the immune system' (72.9\%), 'feel good' (44.0\%), 'protect from COVID-19' (39.1\%) and 'eliminate body deficiency'(35.7\%), respectively. It was determined that more than half of the participants believed that dietary supplements were protective against COVID-19 and that the majority (80.6\%) of those diagnosed with COVID-19 started using dietary supplements. It was determined that the participants obtained information about dietary supplements mostly from the mass media; health professionals, mass media and the social environment were effective in the decision to use dietary supplements The most used dietary supplements during the pandemic were C, D, B group vitamins, ginger, cinnamon, green tea and turmeric. In the study, it was found that gender, educational status, place of residence, marital status, income, occupation, chronic disease status, COVID-19 diagnosis were effective in the use of dietary supplements.

Conclusion: As a result of the research, it was revealed that the use of dietary supplements by adults increased during the COVID-19 pandemic. Although dietary supplements are used to support nutrition or strengthen immunity, they cause health-impairing effects as a result of incorrect information and unconscious use. For this reason, it is important to use dietary supplements under the control of specialists such as a doctor or dietitian and to raise awareness about their effects on health.

Keywords; Dietary supplements, Covid-19, pandemic, immunity, health

Yazışma Adresi: Beyza Kılıçkalkan, Selçuk Üniversitesi, Alaaddin Keykubat Kampüsü, Sağlık Bilimleri Fakültesi Beslenme ve Diyetetik Bölümü, 42250 Selçuklu/Konya, TÜRKIYE

E-Posta: beyzakilickalkan@outlook.com

Alınma tarihi: 31.08.2021 / Kabul tarihi: 27.10.2021 / Yayımlanma tarihi: 15.12.2021

COVID-19 Pandemisi ve Besin Destekleri Kullanımı - Demir ve ark.

Genel Tip Derg 2021;31(4)430-439 
alımının önemli olduğu belirtilmiştir (26). Çin'de yapılan çalışmada, kişilerin selenyum düzeyleri ile COVID-19'dan iyileşme oranlarının

Koronavirüsler, öncelikle solunum sistemini hedef alan, ciddi akut solunum sendromu (SARS-COV-2) olarak bilinmektedir (1). Dünya Sağlık Örgütü (WHO) tarafindan pandemi olarak kabul edilen COVID-19, ülkemizde ve dünyada halk sağlı̆̆ını tehdit etmektedir (2). COVID-19, sistemik bir inflamatuar yanıt veya sitokin salınım sendromu üreterek immün sistemi etkilemektedir. Son dönemde ortaya çıkan bu virüse karşı bağışıklığın olmaması, hastalığın zarar verici etkisini arttırmaktadır (3). Halen kesin bir tedavinin bulunmadığ 1 COVID-19 pandemisi için en önemli hedeflerden biri sağlıklı bir bağışıklık sistemidir (4). Bağışıklık sistemi zayıf olan kişilerin SARS-CoV-2 ile ilişkili komplikasyon geliştirme riskinin daha yüksek olması nedeniyle immün sistemin aktif ve güçlü olması, COVID-19 salgınından korunmada çevresel önlemler ile birlikte önem arz etmektedir (5). Bağışıklık sisteminin düzenlenmesinde, beslenmenin önemli bir faktör olduğu bilinmektedir (6). Araştırmalar, beslenmenin bağışıklık sistemi ve diğer vücut sistemleri üzerinde önemli etkiye sahip olduğunu hem vücudun korunmasını hem de SARS-CoV-2 virüsüyle savaşma yeteneğini geliştirdiğini göstermiş̧ir (7). Bağışıklık sisteminin düzenli bir şekilde çalışması ve sürdürülmesi için vücudun ihtiyaç duyduğu makro ve mikro besin ögelerinin yeterli miktarlarda alınması gerekmektedir (8). A, C, D ve E vitaminleri ile çinko, bakır, selenyum, demir ve probiyotiklerin sağlıklı bir immün fonksiyonu desteklemede ve solunum yolu enfeksiyonu riskini azaltmada kilit rol oynadığı bildirilmiştir (4,9-12).

Besin destekleri; sağllğı ve beslenmeyi desteklemek amaciyla, besin ögelerinin veya bunların dışında besleyici veya fizyolojik etkileri olan bitki, bitkisel ve hayvansal kaynaklı maddeler, biyoaktif bileşenler ve benzeri maddelerin konsantre veya ekstrelerinin tek başına ya da karışımlarının, kapsül tablet vb. gibi formlarda hazırlanarak günlük alım dozu belirlenmiş ürünleri ifade etmektedir (13). Sağlıklı yaşam biçiminde artış, medyada sağlıkla ilgili bilgilerin ön planda olması, sağlı hizmetlerine erişimin kolaylaşması gibi faktörlerin etkisiyle bireyler sağlıkla ilgili konularda kendileri karar verme eğilimindedir (14). COVID-19 salgınının hızla yayılması, dünya çapında birçok endişeyi de beraberinde getirmiş ve bağışıklığı artırmak, hastalığın bulaşmasını önlemek veya hastalığın seyrini hafifletmek için doğal ürünler ve bitki özlerinin kullanılması gibi alternatif seçeneklere olan talebi arttırmıştır (15-19). Birleşik Krallık, Mart 2020'nin başlarında ulusal kapanmaya gidilen dönemde $\mathrm{C}$ vitamini satışlarında $\% 110$, multivitamin takviyeleri satışlarında ise \%93 artış olduğunu bildirmiştir. Benzer şekilde ABD'de COVID-19 endişesinin en yüksek olduğu dönemde, çinko takviyesi satışlarında \%415 artış gözlenmiştir (20-22). Türkiye'de COVID-19 virüsüyle enfekte ilk vakanın açıklandığı Mart 2020'de Google verilerine göre 'vitamin' aramalarının son beş yılın en yüksek verileri olduğu belirlenmiştir. Pandemi sürecinde Türkiye'de vitamin kullanımına olan ilgi artmış, $\mathrm{C}$ ve $\mathrm{D}$ vitaminleri en çok aranan vitamin türleri olmuştur (23). Türkiye'de COVID-19'a karşı vücut direncini arttırmak için takviye kullanımı, salgın başında \%29.0 iken bu oran son dönemde \%43.0'e yükselmiştir (24).

Çalı̧̧malar besin destekleri ve bitkisel ürünlerin solunum yolu, viralparaziter, bulaşıcı ve enflamatuar hastalıklar üzerindeki olumlu sağlık etkilerini göstermiştir (25). D vitamini düzeyleri oldukça düşük olan İtalya, İspanya ve İsviçre'deki yaşlı popülasyonlarda, SARS-CoV2'ye bağlı enfeksiyon görülme sıklığının fazla olduğu bulunmuş ve COVID-19 salgınına karşı korunmak için D vitamini takviyesi ilişsili olduğu tespit edilmiştir (27). Ayrıca, on saatten fazla ventilasyon gereken hastalarda günlük 1-6 g C vitamini takviyesinin ventilasyon süresini ortalama $\% 25$ azalttı̆̆ 1 (28), günde $50 \mathrm{mg}$ 'a kadar çinko tüketiminin COVID-19'a karşı ek koruma sağladığı (29) yapılan araştırmalarla saptanmıştır.

Çeşitli biyoaktif bileşiklerin bağışıklık arttırıcı, anti-inflamatuar, antioksidan ve antiviral özellikleri hakkında bilimsel kanıtlar bulunmasına rağmen COVID-19 tedavisine yönelik kılavuzlar, besin desteklerinin kullanımı hakkında bilgi içermemektedir (22,30). Avrupa Gıda Güvenliği Otoritesi (EFSA), belirli besin öğelerinin yeterli alımını sağlamak ve meydana gelen yetersizlikleri düzeltmek amacıyla besin desteklerinin kullanılabileceğini belirtmiştir. Bununla birlikte; EFSA, besin desteklerinin aşırı tüketimine bağlı yan etkilerin görülmemesi için güvenli üst alım sınırlarının bilinmesi gerektiğini vurgulamaktadır (31). Besin desteklerinin bilinçsiz kullanımı; gastrointestinal semptomlar, nörolojik bozukluklar, karaciğerde toksisite, böbrek fonksiyonu bozuklukları, doğum defektleri gibi ciddi sağlik sorunlarına ve istenmeyen ilaç etkileşimlerine neden olabilmektedir (32).

A, D, E ve K vitaminleri gibi yağda çözünen vitaminlerin yüksek dozda alınması, bu vitaminlerin vücutta depolanarak toksik hale gelmesine hatta ölüme yol açabilmektedir (33). Benzer şekilde demir, bakır ve selenyum gibi minerallerin aşırı doz kullanımlarının da immün yanıtı olumsuz etkileyebileceği bilinmektedir (34). Bitkisel besin destek ürünlerinden ekinezyanın cerrahi müdahalelerde bağışıklık sistemini baskılayabileceği, gingkonun ishal, bulantı kusma gibi etkileri olabileceği, ginsengin ise ishal, hiperaktivite, uykusuzluk gibi yan etkiler yapabileceği belirtilmiştir (35). Özellikle bulaşıcı hastalıkların ortaya çıktığı dönemlerde bireylerin uzman tavsiyesine ihtiyaç duymadan besin destekleri kullanımında büyük artış görülebilmektedir (36). Çalışmalar besin desteklerinin, belirli bir hastalık veya vücuttaki yetersizlik durumlarında doktor ve diyetisyen kontrolünde kullanılmasını ve sağlığa etkileri konusunda farkındalığın artırılmasını tavsiye etmektedir. Bireylerin bu konuda bilinçlendirilmesinin yararlı olacağı düşünülmektedir (36-38).

Bu araştırmada, COVID-19 pandemisi sürecinde yetişkin bireylerin besin destekleri (vitamin-mineral ve bitkisel ürün) kullanımlarının incelenmesi amaçlanmıştır. Çalışmadan elde edilen verilerin, pandemi döneminde Türkiye'deki besin desteği kullanım durumuna ilişkin bulgular sunması açısından literatüre katkı sağlayacağı düşünülmektedir.

\section{Gereç ve Yöntem}

Tanımlayıcı ve kesitsel nitelikte olan bu araştırma, Mayıs 2021-Ağustos 2021 tarihleri arasında gerçekleştirilmiştir. Araştırmanın evrenini Türkiye'de yaşayan 18-65 yaş arası yetişkin bireyler oluşturmaktadır. Çalı̧̧manın örneklemi, G*Power 3.1.9.4 programı ile hesaplanmıştır. Referans araştırma olarak; Bellikci-Koyu ve ark (2020) tarafından yapılan çalışmadan alınan referans orana göre katılımcılar tarafından en fazla tercih edilen besin destekleri \%24.9 oranıla vitamin ve mineral tabletleridir (39). Buna göre; bilinen oran (\%24.9), \%5'lik standart sapma ve \%99'luk güç ile hesaplanarak en az 386 bireye ulaşılması gerektiği saptanmıştır (40). Araştırmaya, 402 gönüllü birey katılmıştır. 
Araştırmanın verileri, araştırmacılar tarafindan "Google Formlar" aracılığıyla geliştirilen online anket formu ile toplanmıştır. Çalışmada uygulanan anket formunun geliştirilmesi aşamasında konuyla ilgili yerli ve yabancı literatür kaynaklarından yararlanılmışırı (39,41-46). Katılımcıların beyanlarıyla elde edilen vücut ağırlığ $(\mathrm{kg})$ ve boy uzunlukları (cm) kullanılarak Beden Kütle İndeksi (BKİ) değerleri, vücut ağırlığ $1(\mathrm{~kg}) /$ boy2 $(\mathrm{m} 2)$ formülüne göre hesaplanmıştır. BKI sınıflandırmasında WHO kriterleri kullanılmıştır (47).

Bu araştırma için, Selçuk Üniversitesi Sağlık Bilimleri Fakültesi Etik Kurul Komitesinin 2021/719 sayılı kararı ile etik onay alınmıştır. Katılımcılar, online olarak araştırmanın amacı ve yöntemi hakkında tam olarak bilgilendirilmiş ve çalışmaya katılmayı kabul ettiklerine dair onamları alındıktan sonra anket uygulanmıştır.

\section{İstatistiksel Analiz}

Verilerin istatistiksel analizinde IBM SPSS 20.0 programı kullanılmıştır. Verilerin analizinde frekans dağılımı (n), ortalama $(\bar{x})$, standart sapma (SD) ve ilişkilerin test edilmesi için iki veya daha fazla bağımsız grubun yüzdeleri arasındaki farkın karşılaştııılmasında 2x2 tablolarında en küçük beklenen frekans $>25$ ise Pearson Ki-kare Test, $5-25$ ise Yates' Ki-kare Test, $<5$ ise Fisher Exact Testi uygulanmıştır. $2 \times 3 \mathrm{vb}$. çoklu gruplarda ise veri gözeneklerinde 5 'ten küçük beklenen frekans yüzdesi $<\% 20$ ise, Pearson Ki-kare testi, $>\% 20$ ise Exact yöntemi uygulanmıştır (48). Farklılıkların ve ilişkilerin test edilmesi için \%95.0 güven aralığında, $\mathrm{p}<0.01$ ve $\mathrm{p}<0.05$ anlamlı kabul edilmiştir.

\section{Bulgular}

Araştırmada yaşları 18-65 arasında değişen toplam 402 kişi yer almıştır (ortalama yaş: $36.3 \pm 11.7$ y1l). Katılımcıların \%58.7'si (n=236) kadın, \%41.3'ü $(n=166)$ erkektir. \%3.9'u, ilköğretim, \%18.2'si lise, \%68.7'si üniversite, \%9.2'si lisansüstü eğitim mezunudur. Katılımcıların \%68.9'u çalışmaktadır. Meslek dağılımları incelendiğinde; \%38.3'ünün memur, \%19.9'unun işçi, \%15.2'sinin öğrenci, \%11.9'unun sağl1k personeli ve \%1.7'sinin esnaf olduğu belirlenmiştir. Çalışmada yer alan katılımcıların \%69.9'u gelir düzeyinin 'orta' olduğunu belirtirken, \%25.1'i 'iyi', \%5.0'i ise 'kötü' olarak değerlendirmiştir. Katılımcıların \%59.0'u şehirde, \%41.0'i köy, kasaba veya ilçede yaşamaktadır. \%59.9'u evlidir ve yarıya yakını (\%48.8) eşi ve çocuğu/çocuklarıyla yaşamaktadır (Tablo 1).

Tablo 2'de, katılımcıların COVID-19 pandemi sürecinde sağlık durumları ve yaşam biçimlerine ilişkin bulgular yer almaktadır. Katılımcıların beyanları doğrultusunda yapılan BKİ değerlendirmesine göre \%48.8'inin normal ağırlıkta, \%35.6'sının hafif kilolu, \%13.4'ünün obez ve \%2.2'sinin zayıf olduğu bulunmuştur. Katılımcıların \%37.3'ünde kronik hastalık öyküsü bulunmaktadır. \%25.9'u sigara, \%12.7'si alkol kullanmaktadır. Düzenli fiziksel aktivite yapanların oran $\% 50.5$ olup en çok yapılan fiziksel aktivite türleri sırasıyla, tempolu yürüyüş (\%65.0) ve aerobik egzersizlerdir (\%11.8). Katılımcıların \%15.4'ü COVID-19 tanısı aldığını belirtmiştir. Katılımcıların \%39.1'i pandemi sürecindeki beslenmesinde herhangi bir değişiklik olmadığını belirtirken, \%34.3'ü pandemi sürecinde daha sağlıklı beslendiğini, \%26.6'sı ise beslenmesinin olumsuz yönde değiştiğini ifade etmiştir. Katılımcıların \%29.9'u pandemi sürecinde diyet uyguladığını belirtmiştir.

Tablo 3'te, katılımcıların besin desteklerine ilişkin bilgi kaynakları ve inançlarına ilişkin bulgular verilmiştir. Katılımcıların besin desteklerine ilişkin bilgi kaynakları incelendiğinde en çok bilgi edinilen kaynağın kitle iletişim araçları (radyo, TV, internet siteleri, sosyal medya, kitap, gazete, dergi vb.) (\%26.1) olduğu, bunu sağlik personelinden (\%19.1) bilgi alanların takip ettiği saptanmıştır.

\begin{tabular}{|c|c|c|c|c|c|c|}
\hline \multirow[t]{2}{*}{ Demografik Özellikler } & \multicolumn{2}{|c|}{ Kadın $(n: 236)$} & \multicolumn{2}{|c|}{ Erkek $(n: 166)$} & \multicolumn{2}{|c|}{ Toplam $(n: 402)$} \\
\hline & $n$ & $\%$ & $\bar{n}$ & $\%$ & $n$ & $\%$ \\
\hline Yas (yll) $(\overline{\mathrm{X}} \pm \mathrm{SD})$ (Alt-Ǔst) & \multicolumn{2}{|c|}{$\begin{array}{c}33.7 \pm 10.9 \\
(18-64) \\
\end{array}$} & \multicolumn{2}{|c|}{$\begin{array}{c}39.9 \pm 11.8 \\
(18-65)\end{array}$} & \multicolumn{2}{|c|}{$\begin{array}{c}36.3 \pm 11.7 \\
(18-65) \\
\end{array}$} \\
\hline \multicolumn{7}{|l|}{ Medeni Durum } \\
\hline Evli & 123 & 52.1 & 118 & 71.1 & 241 & 59.9 \\
\hline Bekâr & 105 & 44.5 & 46 & 27.7 & 151 & 37.6 \\
\hline Boșanmıș/Dul & 8 & 3.4 & 2 & 1.2 & 10 & 2.5 \\
\hline \multicolumn{7}{|l|}{ Eğitim Düzeyi } \\
\hline Illköğretim & 12 & 5.1 & 4 & 2.4 & 16 & 3.9 \\
\hline Lise & 43 & 18.2 & 30 & 18.1 & 73 & 18.2 \\
\hline Üniversite & 155 & 65.7 & 121 & 72.9 & 276 & 68.7 \\
\hline Lisansūstü & 26 & 11.0 & 11 & 6.6 & 37 & 9.2 \\
\hline \multicolumn{7}{|l|}{ Çalışma Durumu } \\
\hline Çalıșıyor & 137 & 58.1 & 140 & 84.3 & 277 & 68.9 \\
\hline Calısmıyor & 99 & 41.9 & 26 & 15.7 & 125 & 31.1 \\
\hline \multicolumn{7}{|l|}{ Meslek/Uğraş } \\
\hline Memur & 77 & 32.6 & 77 & 46.5 & 154 & 38.3 \\
\hline Sağlık personeli & 33 & 14.0 & 15 & 9.0 & 48 & 11.9 \\
\hline İșçi & 32 & 13.6 & 48 & 28.9 & 80 & 19.9 \\
\hline Esnaf & 2 & 0.8 & 5 & 3.0 & 7 & 1.7 \\
\hline Öğrenci & 49 & 20.8 & 12 & 7.2 & 61 & 15.2 \\
\hline Emekli & 11 & 4.7 & 9 & 5.4 & 20 & 5.0 \\
\hline Ev hanımı & 32 & 13.5 & 0 & 0.0 & 32 & 8.0 \\
\hline \multicolumn{7}{|l|}{ Algilanan Gelir Düzeyi } \\
\hline Iyi & 59 & 25.0 & 42 & 25.3 & 101 & 25.1 \\
\hline Orta & 168 & 71.2 & 113 & 68.1 & 281 & 69.9 \\
\hline Kötü & 9 & 3.8 & 11 & 6.6 & 20 & 5.0 \\
\hline \multicolumn{7}{|l|}{ Yaşadığı Yer } \\
\hline Köy/Kasaba/liçe & 63 & 26.7 & 102 & 61.4 & 165 & 41.0 \\
\hline Șehir & 173 & 73.3 & 64 & 38.6 & 237 & 59.0 \\
\hline \multicolumn{7}{|l|}{ Kiminle/nerede yaşadığı } \\
\hline Yalnız & 18 & 7.6 & 22 & 13.2 & 40 & 9.9 \\
\hline Eși ve çocuğu/çocuklarıyla & 99 & 42.0 & 97 & 58.4 & 196 & 48.8 \\
\hline Eșiyle & 22 & 9.3 & 21 & 12.7 & 43 & 10.7 \\
\hline Anne-babasıyla & 87 & 36.9 & 21 & 12.7 & 108 & 26.9 \\
\hline Çocuklarıyla & 6 & 2.5 & 0 & 0.0 & 6 & 1.5 \\
\hline Ev arkadașıyla & 4 & 1.7 & 5 & 3.0 & 9 & 2.2 \\
\hline
\end{tabular}

\begin{tabular}{|c|c|c|}
\hline & $n$ & $\%$ \\
\hline \multicolumn{3}{|l|}{ Beden Kütle İndeksi (BKí) } \\
\hline Zayif & 9 & 2.2 \\
\hline Normal & 196 & 48.8 \\
\hline Hafif kilolu & 143 & 35.6 \\
\hline Obez & 54 & 13.4 \\
\hline \multicolumn{3}{|l|}{ Kronik hastalık durumu } \\
\hline Var & 150 & 37.3 \\
\hline Yok & 252 & 62.7 \\
\hline \multicolumn{3}{|l|}{ Sigara içme durumu } \\
\hline Evet & 104 & 25.9 \\
\hline Hayır & 298 & 74.1 \\
\hline \multicolumn{3}{|l|}{ Alkol kullanma durumu } \\
\hline Evet & 51 & 12.7 \\
\hline Hayır & 351 & 87.3 \\
\hline \multicolumn{3}{|l|}{ Fiziksel aktivite durumu } \\
\hline Evet & 203 & 50.5 \\
\hline Hayır & 199 & 49.5 \\
\hline \multicolumn{3}{|l|}{ Fiziksel aktivite türü (n:203) } \\
\hline Tempolu yürüyüș & 132 & 65.0 \\
\hline Koșu & 12 & 5.9 \\
\hline Yüzme & 5 & 2.5 \\
\hline Aerobik egzersizler & 24 & 11.8 \\
\hline Bisiklet & 12 & 5.9 \\
\hline Ağırlık kaldırma & 7 & 3.4 \\
\hline Takım sporlan (futbol, basketbol vb.) & 3 & 1.5 \\
\hline Yoga/Pilates & 3 & 1.5 \\
\hline Diğer & 5 & 2.5 \\
\hline \multicolumn{3}{|l|}{ Fiziksel aktivite sıklı̆ı̆ (n:203) } \\
\hline Her gün & 41 & 20.2 \\
\hline Haftada $5-6 \mathrm{kez}$ & 21 & 10.3 \\
\hline Haftada $3-4 \mathrm{kez}$ & 71 & 35.0 \\
\hline Haftada $1-2 \mathrm{kez}$ & 52 & 25.6 \\
\hline Ayda birkaç kez & 18 & 8.9 \\
\hline \multicolumn{3}{|l|}{ COVID-19 tanisı alma durumu } \\
\hline Evet & 62 & 15.4 \\
\hline Hayır & 340 & 84.6 \\
\hline \multicolumn{3}{|c|}{ Pandemi sürecindeki beslenme durumu-öz değerlendirme } \\
\hline Daha sağlıklı besleniyorum & 138 & 34.3 \\
\hline Beslenmem olumsuz yönde değiști & 107 & 26.6 \\
\hline Değișiklik olmadı & 157 & 39.1 \\
\hline \multicolumn{3}{|c|}{ Pandemi sürecinde diyet uygulama durumu } \\
\hline Evet & 120 & 29.9 \\
\hline Hayır & 282 & 70.1 \\
\hline
\end{tabular}

Katılımcıların \%41.8'inin 'besin destekleri' hakkında bilgisi yoktur. Katılımcıların yarıdan fazlası (\%52.5), besin desteklerinin COVID19'a karşı koruyucu olduğuna inanmaktadır. 
Tablo 3. Katılımcıların besin desteklerine iliskin bilgi ve inançları (n:402)

\begin{tabular}{lcc}
\hline & $n$ & $\%$ \\
\hline Besin destekleri konusunda bilgiyi kimden/nereden aldınız? & 168 & 41.8 \\
Besin destekleri konusunda bilgim yok & 77 & 19.1 \\
Sağlık personelinden (doktor, diyetisyen, hemșire, eczacı vb.) & 1 & 0.3 \\
Antrenörümden & 24 & 6.0 \\
Derslerden & 15 & 3.7 \\
Konferans, seminer gibi bilimsel faaliyetlerden & 105 & 26.1 \\
Kitle iletişim araçlarından (radyo, TV, internet siteleri, sosyal medya, & 12 & 3.0 \\
kitap, gazete, dergi vb.) & & \\
Yakın çevreden (aile/ akraba/arkadaș) & & \\
\hline Besin desteklerinin COVID-19'a karşı koruyucu olduğuna & 211 & 52.5 \\
inanıyor musunuz? & 33 & 8.2 \\
Evet & 158 & 39.3 \\
Hayır & & \\
Kararsızım/ Fikrim yok &
\end{tabular}

Tablo 4'te katılımciların COVID-19 pandemisi sürecinde besin destekleri kullanımlarına ilişkin bilgiler verilmiştir. Katılımcıların \%66.2'si pandemi sürecinde besin destekleri kullanmıştır. Besin desteği kullanma kararında en çok sağlık personelinin (doktor, diyetisyen, hemşire vb.) (\%56.7) etkili olduğu belirlenmiştir (Tablo $4)$.

Katılımcıların besin destekleri kullanım amaçları en yüksek oranda sırasıyla; 'bağışıklık sistemini güçlendirmek' (\%72.9), 'kendini iyi hissetmek'(\%44.0), 'COVID-19'dan korunmak' (\%39.1) ve 'vücuttaki yetersizliği gidermek' (\%35.7) olarak belirlenmiştir. Katılımcıların besin desteklerini en yüksek oranda günde $1 \mathrm{kez}(\% 48.5)$ tükettikleri belirlenmiştir. Pandemi sürecinde besin desteği tüketim miktarını ve/veya sıklığını artıran katılımcıların oranı ise \%54.1'dir. Besin desteklerinin temininde en çok eczaneler (\%72.9) tercih edilmiştir. Katılımcıların \%72.2'si kullandığı besin desteklerinin kendi sağlığ üzerinde olumlu etkisi olduğunu düșünmektedir (Tablo 4).

Katılımcıların pandemi sürecinde kullandıkları vitamin ve mineraller incelendiğinde; \%23.0 ile en yüksek oranda D vitamini kullanıldığı, bunu sırasiyla C vitamini (\%20.6), B grubu vitaminleri (\%13.0), multivitamin-mineral takviyeleri (\%9.7), demir (\%8.8), magnezyum (\%7.5), çinko (\%6.0), folik asit (\%5.0) ve kalsiyumun (\%3.5) izlediğ bulunmuştur. En az oranda kullanılan vitamin-mineral destekleri, koenzim Q10 (\%1.8) ve selenyum (\%1.1) olmuştur (Şekil 1).

Şekil 1. Katılımcıların pandemi süresince kullandıkları vitaminler ve mineraller (\%) (n: 266)

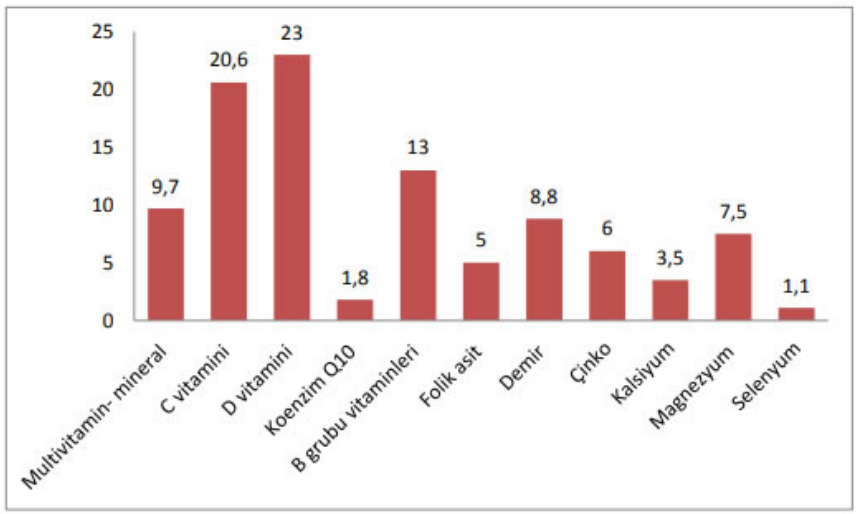

*Katılımcılar bu soruya birden fazla seçenek işaretleyerek cevap vermiştir.

Katılımcıların pandemi süresince kullandıkları bitkisel ürünler ve diğer besin destekleri Şekil 2'de verilmiştir. Bitkisel ürünlerden en çok kullanılanın zencefil (\%18.0) olduğu saptanmıştır. Ardından \%14.1 ile tarçın, \%14.0 ile yeşil çay, \%13.8 ile zerdeçal/kurkumin, $\% 6.7$ ile kara mürver, \%1.6 ile ginseng ve \%1.1 oranıla ekinezya

Genel Tip Derg 2021;31(4)430-439 gelmektedir. Gingko \%0.4 ile en az oranda kullanılan bitkisel ürün olmuştur. Balık yağı/omega-3 (\%9.5), probiyotik (\%8.5), propolis (\%5.8), kolajen (\%4.4), beta glukan $(\% 1.4)$ ve krill yağı $(\% 0.7)$ ise pandemi sürecinde katılımcılar tarafından kullanılan diğer besin destekleridir.

Şekil 2. Katılımcıların pandemi süresince kullandıkları bitkisel ürünler ve diğer besin destekleri (\%) (n:266)

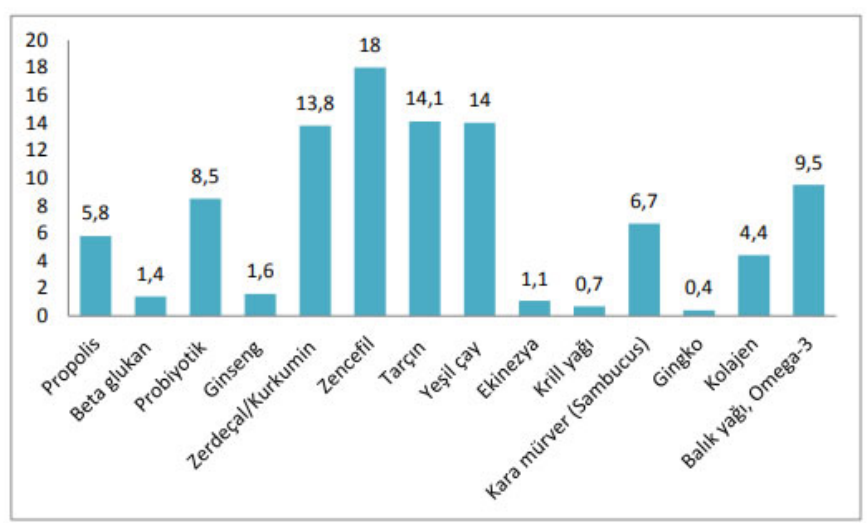

*Katılımcılar bu soruya birden fazla seçenek işaretleyerek cevap vermiştir.

Tablo 4. Katılımcıların COVID-19 pandemisi sürecinde besin destekleri kullanımlarına ilişkin
bulgular

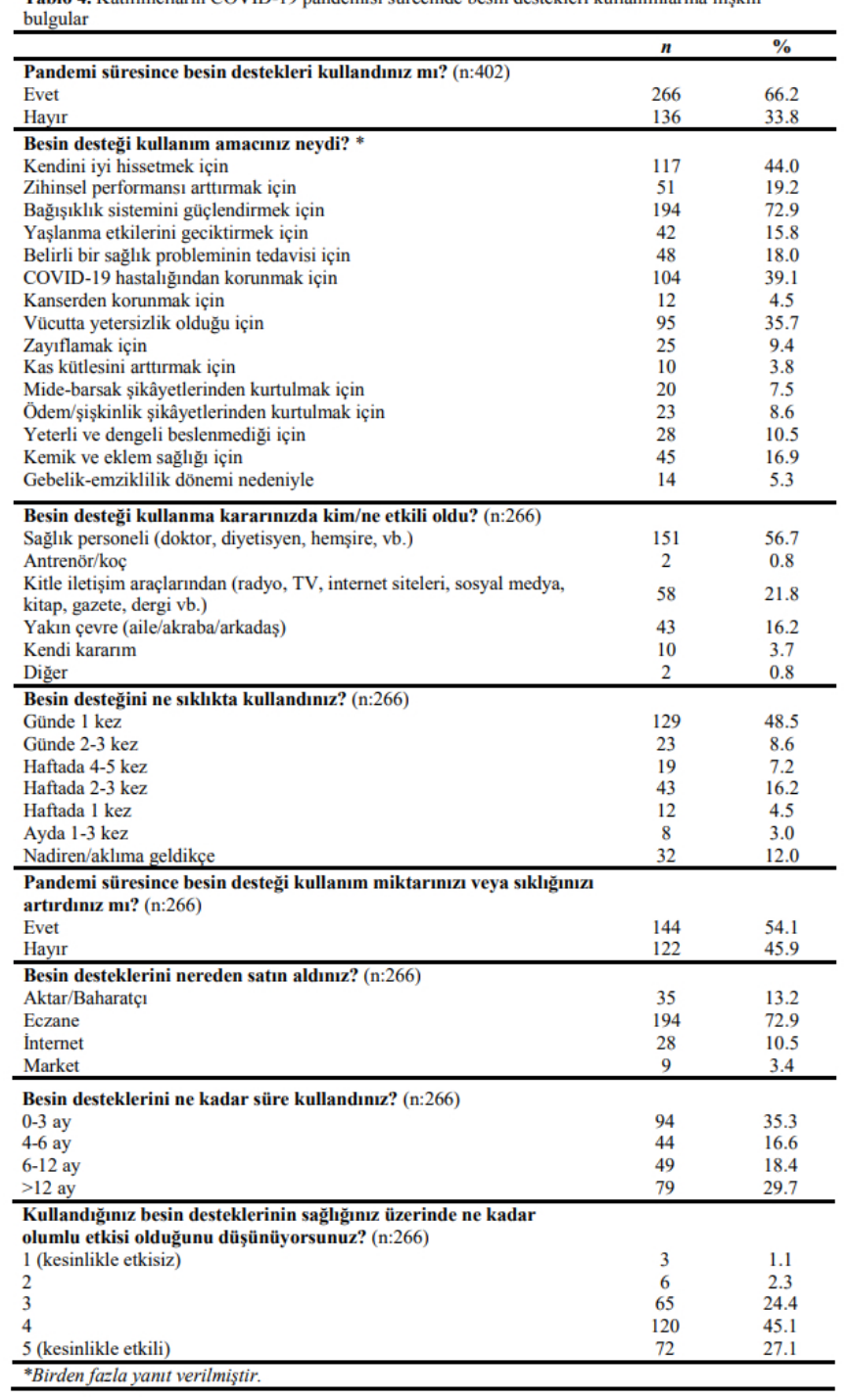

Tablo 5'te, katılımcıların pandemi sürecinde besin destekleri kullanım 
durumları bazı değişkenlere göre incelenmiştir. Pandemi sürecinde besin destekleri kullanımı, kadın ve erkek katılımcılar arasında anlamlı bir farklılık göstermektedir ( $\mathrm{p}<0.01)$. Kadınların destekleri kullanımı (\%73.3), erkeklere (\%56.0) oranla daha yüksektir. Katılımcıların besin desteği kullanımları yaşa göre incelendiğinde, istatistiksel olarak anlamlı farklılık olmamakla birlikte, 26-35 yaşındakilerin pandemi sürecinde besin destekleri kullanımının (\%72.7) daha yüksek olduğu belirlenmiştir ( $>00.05)$. Pandemi sürecinde besin destekleri kullanımı ile medeni durum $(p<0.05)$, ögrenim durumu $(p<0.01)$ ve yaşanılan yer $(\mathrm{p}<0.01)$ arasındaki farklılık istatistiksel açıdan anlamlıdır. Boşanmış veya dul olan katılımcıların bu süreçte besin desteği kullanım (\%100.0), diğer katılımcılara kıyasla daha yüksektir. Benzer şekilde, lisansüstü eğitim mezunu (\%89.2) olanların pandemi sürecinde besin destekleri kullanımı, üniversite mezunu (\%65.9) ve ilköğretim/lise (\%57.3) mezunu olan katılımcılara göre daha yüksektir. Pandemi sürecinde besin destekleri kullanan katılımciların yarıdan fazlası şehirde (\%73.4) yaşamaktadır. Köy, kasaba veya ilçede yaşayan katılımcıların pandemi sürecinde besin destekleri kullanımının (\%55.8), şehirde yaşayan katılımcılarla karşılaştırıldığında daha düşük oranda olduğu belirlenmiştir $(\mathrm{p}<0.01)$. Pandemi sürecinde çalışan bireylerin besin desteği kullanımının daha fazla olduğu bulunmuştur ( $>0.05$ ). Katılımcıların pandemi sürecinde besin destekleri kullanımı ile meslek/uğraşları arasındaki ilişki istatistiksel olarak anlamlı olup, besin desteği kullanan katılımcıların çoğunluğunu sağlık personeli (\%87.5) oluşturmaktadır. Pandemi sürecinde besin destekleri kullanımı en az olan meslek grubu işçi ve esnaflardır (\%57.5), $(\mathrm{p}<0.01$, Tablo 5). Araştırmaya katılanlarda algılanan gelir düzeyi ile pandemi sürecinde besin destekleri kullanımı ilişkilidir $(\mathrm{p}<0.05)$. Besin desteği kullanım oranı en düşük olan katılımcılar, gelir düzeyinin 'kötü' olduğunu bildirenlerdir (\%40.0). Pandemi sürecinde besin destekleri kullanımı, BKİ'ye göre değişmemektedir. Bununla birlikte; normal ağırlıkta olan katılımcıların besin desteği kullanım sıklığının, istatistiksel olarak anlamlı olmasa da oransal olarak daha yüksek (\%69.9) olduğu saptanmıştır ( $p>0.05$, Tablo 5). Katılımcıların besin desteği kullanımları kronik hastalığ 1 bulunma durumuna göre incelendiğinde; kronik hastalığa sahip olan katılımcıların pandemi sürecinde besin destekleri kullanımının (\%72.7) daha yüksek olduğu ve bu oranın istatistiksel açıdan anlamlı olduğu belirlenmiştir $(\mathrm{p}<0.05)$. Aynı şekilde, pandemi sürecinde besin destekleri kullanımı ile COVID-19 tanısı olma durumu arasındaki fark istatistiksel olarak anlamlıdır $(\mathrm{p}<0.05)$. COVID-19 tanısı olan katılımcilarda (\%80.6) bu süreçteki besin destekleri kullanımı, COVID-19 tanısı olmayanlara (\%63.5) oranla daha yüksektir.

\section{Tartışma}

COVID-19 salgını, dünya çapında bireylerin yaşam tarzlarını, önemli ölçüde etkilemektedir (49). Bu süreçte bireylerin sağlık ve beslenme davranışları üzerinde olumsuz etkiler ortaya çıkmıştır. Salgın dönemindeki bu olumsuz etkilerin bireylerin beslenme ve uyku düzeninde değişimlere, ağırlık artışına, sigara ve alkol kullanımında artışa, kronik sağlık koşullarının kötüleşmesine neden olabileceği bildirilmektedir (50-52). Bu dönemi bireylerin en sağliklı şekilde yönetebilmeleri açısından sağlıklı yaşam davranışları göstermeleri önemlidir. Çalışmada katılımcıların \%26.6's1, pandeminin beslenmelerini olumsuz yönde etkilediğini bildirmiștir. Katılımcıların BKI'leri değerlendirildiğinde de yaklaşık yarısının (\%49.0) hafif kilolu veya obez oldukları bulunmuştur. Ayrıca pandemi sürecinde, \%25.9'u sigara, \%12.7'si alkol kullandığını bildirmiştir. Katılımcıların ancak yarısının $(\% 50.5)$ bu süreçte düzenli fiziksel aktivite yaptıkları saptanmıştır (Tablo 2). Türkiye'de yapılan bir çalışmada da COVID-19 pandemi sürecinde bireylerin normalden daha fazla besin tükettikleri, karbonhidrat yönünden zengin besin tüketimlerinin ve BKİ'lerinin arttığı belirlenmiştir (53). Uluslararası çalışmalarda da bireylerin çoğunluğunun pandemi döneminde sağlıksız davranış kalıpları izlediği, beslenmelerinin olumsuz etkilendiği (54) ve besin tüketimlerinin $\operatorname{arttığ~} 1$ bulunmuştur (55).

\begin{tabular}{|c|c|c|c|c|c|c|c|c|c|}
\hline & & \multicolumn{4}{|c|}{$\begin{array}{l}\text { Pandemi Sürecinde Besin } \\
\text { Destekleri Kullanımı }\end{array}$} & \multirow{2}{*}{\multicolumn{2}{|c|}{ Toplam }} & \multirow{3}{*}{$X^{2}$} & \multirow{3}{*}{$p$} \\
\hline & & \multicolumn{2}{|c|}{ Evet } & \multicolumn{2}{|c|}{ Hayır } & & & & \\
\hline & & $\bar{n}$ & $\%$ & $n$ & $\%$ & $\bar{n}$ & $\%$ & & \\
\hline & Kadın & 173 & 73.3 & 63 & 26.7 & 236 & 100.0 & & \\
\hline Cinsiyet & Erkek & 93 & 56.0 & 73 & 44.0 & 166 & 100.0 & $13.001^{\mathrm{a}}$ & $<0.01$ \\
\hline \multirow{4}{*}{ Yaş } & $18-25$ & 49 & 56.3 & 38 & 43.7 & 87 & 100.0 & \multirow{4}{*}{$7.079^{c}$} & \multirow{4}{*}{$>0.05$} \\
\hline & $26-35$ & 96 & 72.7 & 36 & 27.3 & 132 & 100.0 & & \\
\hline & $36-45$ & 61 & 69.3 & 27 & 30.7 & 88 & 100.0 & & \\
\hline & $\geq 46$ & 60 & 63.2 & 35 & 36.8 & 95 & 100.0 & & \\
\hline \multirow{3}{*}{$\begin{array}{l}\text { Medeni } \\
\text { Durum }\end{array}$} & Evli & 153 & 63.5 & 88 & 36.5 & 241 & 100.0 & \multirow{3}{*}{$6.170^{c}$} & \multirow{3}{*}{$<0.05$} \\
\hline & & 103 & 68.2 & 48 & 31.8 & 151 & 100.0 & & \\
\hline & Boșanmıș/Dul & 10 & 100.0 & 0 & 0.0 & 10 & 100.0 & & \\
\hline \multirow{3}{*}{$\begin{array}{l}\text { Öğrenim } \\
\text { Durumu }\end{array}$} & İlköğretim/Lise & 51 & 57.3 & 38 & 42.7 & 89 & 100.0 & \multirow{3}{*}{$11.890^{\mathrm{c}}$} & \multirow{3}{*}{$<0.01$} \\
\hline & Ũnive & 182 & 65.9 & 94 & 34.1 & 276 & 100.0 & & \\
\hline & Lisansüstü & 33 & 89.2 & 4 & 10.8 & 37 & 100.0 & & \\
\hline \multirow{2}{*}{ Yaşanılan Yer } & Köy/Kasaba/iliçe & 92 & 55.8 & 73 & 44.2 & 165 & 100.0 & \multirow{2}{*}{$13.553^{\mathrm{c}}$} & \multirow{2}{*}{$<0.01$} \\
\hline & Sehir & 174 & 73.4 & 63 & 26.6 & 237 & 100.0 & & \\
\hline \multirow{2}{*}{$\begin{array}{l}\text { Calışma } \\
\text { Durumu }\end{array}$} & Çalışıy & 189 & 68.2 & 88 & 31.8 & 277 & 100.0 & \multirow{2}{*}{$1.692^{\mathrm{a}}$} & \multirow{2}{*}{$>0.05$} \\
\hline & Çalıșmıyor & 77 & 61.6 & 48 & 38.4 & 125 & 100.0 & & \\
\hline \multirow{5}{*}{ Meslek/Uğraş } & Memur & 103 & 66.9 & 51 & 33.1 & 154 & 100.0 & \multirow{5}{*}{$14.156^{\mathrm{C}}$} & \multirow{5}{*}{$<0.01$} \\
\hline & Sağlık Personeli & 42 & 87.5 & 6 & 12.5 & 48 & 100.0 & & \\
\hline & İșçi/Esnaf & 50 & 57.5 & 37 & 42.5 & 87 & 100.0 & & \\
\hline & Ögrenci & 36 & 59.0 & 25 & 41.0 & 61 & 100.0 & & \\
\hline & Ev Hanımı/Emekli & 35 & 67.3 & 17 & 32.7 & 52 & 100.0 & & \\
\hline \multirow{3}{*}{$\begin{array}{c}\text { Alglanan } \\
\text { Gelir Düzeyi }\end{array}$} & Iyi & 65 & 64.4 & 36 & 35.6 & 101 & 100.0 & \multirow{3}{*}{$7.060^{c}$} & \multirow{3}{*}{$<0.05$} \\
\hline & Orta & 193 & 68.7 & 88 & 31.3 & 281 & 100.0 & & \\
\hline & Kötü & 8 & 40.0 & 12 & 60.0 & 20 & 100.0 & & \\
\hline & Zayif & 5 & 55.6 & 4 & 44.4 & 9 & 100.0 & & \\
\hline & Normal & 137 & 69.9 & 59 & 30.1 & 196 & 100.0 & $2697^{c}$ & $>0,05$ \\
\hline BKİ-Grup & Hafif Kilolu & 91 & 63.6 & 52 & 36.4 & 143 & 100.0 & 2.697 & $>0.03$ \\
\hline & Obez & 33 & 61.1 & 21 & 38.9 & 54 & 100.0 & & \\
\hline Kronik & Yok & 157 & 62.3 & 95 & 37.7 & 252 & 100.0 & & \\
\hline $\begin{array}{l}\text { Hastahk } \\
\text { Durumu }\end{array}$ & Var & 109 & 72.7 & 41 & 27.3 & 150 & 100.0 & $4.513^{\mathrm{a}}$ & $<0.05$ \\
\hline $\begin{array}{c}\text { COVID-19 } \\
\text { Tanısı }\end{array}$ & $\begin{array}{l}\text { Evet } \\
\text { Hayir }\end{array}$ & $\begin{array}{c}50 \\
216\end{array}$ & $\begin{array}{l}80.6 \\
63.5\end{array}$ & $\begin{array}{c}12 \\
124\end{array}$ & $\begin{array}{l}19.4 \\
36.5\end{array}$ & $\begin{array}{c}62 \\
340\end{array}$ & $\begin{array}{l}100.0 \\
100.0\end{array}$ & $6.119^{b}$ & $<0.05$ \\
\hline & plam & 266 & 66.2 & 136 & 33.8 & 402 & 100.0 & & \\
\hline
\end{tabular}

Yakın zamanda ortaya çıkan COVID-19 pandemisinin hızla yayılması ve COVID-19 tedavisi için üretilen aşılarla istenen hedeflere henüz ulaşılamaması, toplumlar arasında korku ve paniği artırmıştır. Viral ve ilaca dirençli enfeksiyonlarla mücadele için yeni ve etkili farmakolojik tedavilerin eksikliği, viral hastalıkların önlenmesi ve tedavisinde etkili olabilecekleri düşüncesi besin takviyeleri, fonksiyonel gidalar ve bitkisel ürünlere olan bu ilginin artmasına neden olmuştur. Besin takviyeleri ve bitkisel ürünler, tüm yaş gruplarında hastalık için potansiyel etkili bir korunma ve tedavi kaynağı olarak görülmektedir $(17,22,56,57)$.

COVID-19'un bağışıklık sistemi ile ilgili olduğu düşünüldüğünden, bireyler, COVID-19 enfeksiyonunu önlemeye yönelik bir strateji olarak; bağışıklıklarını güçlendirmek için beslenmelerini iyileştirmeye daha fazla dikkat etmektedir. Son zamanlarda çeşitli sosyal medya platformlarında yer alan bilgiler ve besin desteklerinin kullanımının COVID-19 ile mücadeledeki rolünü destekleyen reklamlar, tüm dünyadaki tüketicileri besin destekleri kullanımını artırmaya yöneltmiştir (22,58). Pandemi sürecinde, dünyada, yetişkinlerin besin desteği kullanımlarının incelendiği çalışmalarda, besin desteği kullanım sıklığı; Suudi Arabistan'da \%22.1 (59), Çin'de \%31.2 (60), Hong Kong'da \%25.3 (61), Fas’ta \%69.4 (62) olarak saptanmıştır. Polonya'da yapılan bir çalışmada, pandeminin başlangıcında besin desteği kullanım sıklığ $\%$ 48.0 iken, pandeminin ikinci dalgasında \%79.0'a yükseldiği belirlenmiştir (63). Türkiye'de ise, Türkiye 
Beslenme ve Sağlık Araştırması (TBSA) sonucuna göre 2019 yılında ülke genelinde yetişkinlerde besin destek kullanımı \%9.7 iken (13), pandemi sürecinde kullanım sıklığının arttığını ortaya koyan çalışmalar bulunmaktadır. Örneğin; özel bir araştırma merkezinin yürütmüş olduğu bir araştırmada, Türkiye'de COVID-19'a karş1 vücut direncini arttırmak için takviye kullanımı salgın başında \%29.0 iken bu oran salgının ilerleyen döneminde \%43.0'e yükselmiştir (24). Yine, spor salonlarına devam eden bireyler üzerinde yürütülen bir çalışmada, besin desteği kullanım sıklığı; \%41.2 (64); diyetisyenler üzerinde yürütülen bir çalışmada ise $\% 94.5$ olarak bulunmuştur (36). Bizim çalışmamızda da benzer şekilde, pandemi sürecinde yetişkinlerin besin desteği kullanım sıklığı \%66.2 olarak saptanmış olup son TBSA verilerine kıyasla artış olduğu belirlenmiştir (Tablo 4).

Çalışmamızda katılımcıların \%41.8'i 'besin destekleri' hakkındabilgisi olmadığını bildirmiştir. Konu hakkında bilgisi olan katılımcıların besin desteklerine ilişkin bilgi kaynakları incelendiğinde ise, en çok bilgi edinilen kaynağın kitle iletişim araçları (\%26.1) olduğu, ikinci sırada ise sağlık personelinin geldiği (\%19.1) ortaya çıkmıştır (Tablo 3). Bununla birlikte; katılımcıların besin desteği kullanma kararında en çok sağlık personelinin (\%56.7) etkili olduğu belirlenmiştir (Tablo 4). Pandemi sürecindeki besin desteği kullanımını inceleyen farklı araştırmalarda da bu çalışmanın bulgularına benzer şekilde; besin desteği kullanma kararında en çok sağlık personeli etkili olmuştur $(54,62,63,65)$.

Çalışmaya göre, katılımcıların yarıdan fazlası (\%52.5), besin desteklerinin COVID-19'a karşı koruyucu olduğuna inanmaktadır (Tablo 3). Katılımcıların besin destekleri kullanım amaçları ise; en yüksek oranda sırasıyla 'bağışıklık sistemini güçlendirmek' (\%72.9), 'kendini iyi hissetmek' (\%44.0), 'COVID-19'dan korunmak' (\%39.1) ve 'vücuttaki yetersizliği gidermek' (\%35.7) olarak belirlenmiştir (Tablo 4). Türkiye'de, bireylerin pandemi sürecinde besin destekleri kullanım amaçlarının incelendiği farklı çalışmalarda da bağışıklık sistemini güçlendirmek amaçlı kullanımın ilk sırada olduğu saptanmıştır $(64,66)$. Yine ülkemizde, diyetisyenler üzerinde yürütülen bir çalışmada da bu çalışmanın bulgularına benzer şekilde; katılımciların \%34.9'unun COVID-19'dan korunmak amaciyla besin desteği kullandıkları belirlenmiştir (36). Uluslararası literatür incelendiğinde ise; pandemi sürecinde, Polonya'da yapılan çalışmada, besin destekleri kullanım amaçları sırasıyla; bağışıklığı güçlendirmek (\%60.0), genel sağlık ve zindeliği iyileştirmek (\%57.0), diyetteki eksik besin ögelerini yerine koymak (\%53.0) şeklinde bulunmuştur (63). Fas'ta yapılan çalışmada ise; katılımcıların besin desteklerini bağışıklığı güçlendirmek (\%21.3), diyeti dengelemek (\%10.5) ve estetik bir amaca ulaşmak için (\%6.9) kullandıkları belirlenmiştir (62). Çalışmada, katılımcıların yarısından fazlasının (\%54.1) pandemi sürecinde besin desteği tüketim miktarını ve/veya sıklığını artırdıkları saptanmıştır (Tablo 4). Literatürden ve çalışmamızdan elde edilen bulgular doğrultusunda, pandemi sürecinde bireylerin bağışıklık sistemini güçlendirmek ve sağlığı korumak amaçlı besin destekleri kullanımının arttı̆̆ını söyleyebiliriz.

Araştırmaya katılan tüm katılımcıların yarıdan fazlası (\%52.5), besin desteklerinin COVID-19'a karşı koruyucu olduğuna inanmakta (Tablo 3); pandemi sürecinde besin desteği kullandığını bildiren katılımcıların \%72.2'si kullandığg besin desteklerinin kendi sağlığ üzerinde olumlu etkisi olduğunu düşünmektedir (Tablo 4). Türkiye'de yapılan başka bir çalışmada katılımcıların, C vitamini (\%9.2) ve D vitamini (\%9.5) almayanların daha çabuk hastalandığına ve besin desteklerinin virüsü yok edeceğine yönelik (\%7) görüşleri olduğu belirlenmiştir (66).

Toplumda s1k görülen vitamin-mineral eksiklikleri, medyada popüler olan ürünler, güncellenen bilimsel bilgiler, uygulanan sağllk politikaları, ortaya çıkan hastalıklar ve yeni tedavi yöntemleri, kullanılan besin desteklerinin türünü etkilemektedir (39). Çalışmamızda pandemi sürecinde katılımcıların en çok kullandıkları vitamin ve mineraller sirasılya; D vitamini (\%23.0), C vitamini (\%20 .6), B grubu vitaminleri (\%13.0), multivitamin-mineral (\%9.7), demir $(\% 8.8)$ ve magnezyumdur (\%7.5) (Şekil 1). Bitkisel ürünler ve diğer besin destekleri ise sirasıyla; zencefil (\%18.0), tarçın (\%14.1), yeşil çay (\%14.0), zerdeçal/kurkumin (\%13.8) ve balık yağ1/ omega-3 (\%9.5) olarak belirlenmiştir (Şekil 2). TBSA 2019'a göre pandemi öncesinde 19 yaş ve üzeri bireylerin en sık kullandıkları besin destekleri; B12 vitamini ve D vitaminidir (13). Türkiye'de pandemi sürecinde yapılan bir çalışmada ise; en çok kullanılan besin desteklerinin sirasılyla C vitamini (\%43.6), D vitamini (\%37.7) ve probiyotik gidalar (\%12.9) olduğu bulunmuştur (66). Pandemi döneminde yapılan bir başka çalışmaya göre de en sık kullanılan besin destekleri sırasıyla; balık yağ 1 (\%81.9), D vitamini (\%39.0), multivitamin (\%27.4), probiyotikler (\%22.3) ve C vitamini (\%19.4) dir (36). Fas'ta yapılan araştırmada, COVID-19 pandemisi sırasında 23 farklı tıbbi bitki türünün kullanıldığı, en yaygın kullanılan bitkilerin; sarımsak, zeytin, soğan ve zencefil olduğu belirlenmiştir (67). Suudi Arabistan'da yapılan çalışmada da, bağışıklığı artırmak ve COVID-19 hastalığından korunmak için en sık zencefil, soğan ve sarımsak kullanıldığı belirtilmiştir (59). Çin'de yapılan bir çalışmada ise; katılımcıların COVID-19'dan korunmak için C vitamini (\%18.2), probiyotik (\%11.7) ve sirke tükettikleri saptanmıştır (60).

Son yıllarda yapılan geniş çaplı araştırmalar; toplumlarda genel olarak düzenli besin destekleri kullanımının giderek yaygınlaştığını, bununla birlikte kadınların besin desteklerini erkeklere göre daha s1k kullandığını ve ilerleyen yaş ile birlikte artan besin destekleri kullanımı arasındaki ilişkiyi göstermektedir (68-72). Ayrıca, eğitim düzeyi yüksek, BKİ'leri düşük olanlar, yaşlllar, fiziksel aktivite düzeyi yüksek olanlar arasında takviye kullanımının daha fazla olduğu belirtilmektedir (35).

Suudi Arabistan'da ve ABD'de yapılan iki farklı çalışmada COVID-19 sürecinde erkekler arasında besin takviyeleri kullanım sıklığının, kadınlara kıyasla daha yüksek olduğu saptanmıştır $(54,73)$. Fas'ta üniversite öğrencileri üzerinde yapılan başka bir çalışmada, pandemi sürecinde besin destekleri kullanımı her iki cinsiyette de benzer bulunmuştur (erkek \%35.4, kadın \%34.0) (62). Polonya'da ise pandemi süresince besin destekleri kullanımı, kadınlarda erkeklere göre anlamlı düzeyde daha yüksek saptanmıştır (63). Bizim çalışmamızda da, pandemi sürecinde kadınlarda besin destekleri kullanımı (\%73.3), erkeklere (\%56.0) oranla daha yüksek bulunmuştur $(\mathrm{p}<0.01$, Tablo 5). Yapılan çalışmalarda kadınlar ve erkekler arasında besin destekleri kullanımı açısından farklı sonuçlar elde edilmesi, seçilen örneklemlerin farklı sosyo-demografik özellikleriyle ilişkili olabilir.

Katılımcıların besin desteği kullanımları yaşa göre incelendiğinde, pandemi sürecinde besin destekleri kullanımının 26-35 yaş aralığında daha yüksek olduğu saptanmıştır ( $p>0.05$, Tablo 5). Farklı ülkelerde yapılan çalışmalarda da pandemi sürecinde genç katılımcıların besin destekleri kullanımı, bizim çalışmamıza benzer şekilde anlamlı olarak daha yüksek bulunmuştur $(62,63,73)$. 
Çalışmamızda pandemi sürecinde besin destekleri kullanımı ile medeni durum $(\mathrm{p}<0.05)$ ve yaşanılan yer $(\mathrm{p}<0.01)$ arasındaki farklılık istatistiksel açıdan anlamlıdır. Boşanmış/dul ve şehirde yaşayan katılımcıların pandemi sürecinde besin desteği kullanımı diğer katılımcılara kıyasla daha yüksektir (Tablo 5). Benzer şekilde Polonya'da şehirde yaşayan katılımcılarda kullanım oranı daha yüksek bulunmuştur (63).

Eğitim düzeyinin yükselmesiyle birlikte sağlik konusunda farkındalığın ve bilinç düzeyinin artması, bireylerin sağlıklarını geliştirmeye yönelik yaşam ve beslenme davranışları sergilemelerinde etkili olmaktadır (74). Literatürdeki birçok çalışma, yüksek eğitim düzeyi ile besin desteği kullanımındaki artışın ilişsili olduğunu göstermektedir (63,68-70,75-78). Yapılan bu çalışmada ise eğitim seviyesi yükseldikçe katılımcıların besin desteği kullanımlarının arttığ1 görülmüştür $(\mathrm{p}<0.01)$. Lisansüstü mezunu olanların, pandemi sürecinde besin destekleri kullanımı daha yüksektir (Tablo 5). Bu sonucun, katılımcıların eğitim seviyesi ve algılanan gelir düzeyi yükseldikçe besin desteklerine erişilebilirliklerinin artmasından kaynaklanabileceği düşünülmektedir.

Araştırmamızda, katılımcıların pandemi sürecinde besin destekleri kullanımı ile meslek/uğraşları arasındaki ilişki anlamlı olup, besin desteği kullananların çoğunluğunu sağllk personelleri (\%87.5) oluşturmaktadır. Pandemi sürecinde besin destekleri kullanımı en az olan meslek grubu işçi ve esnaflardır (\%57.5), ( $\mathrm{p}<0.01$, Tablo 5). Çalışmalar, sağlık eğitimi alan bireylerde besin destekleri kullanımının toplumun geneline göre daha yaygın olduğunu göstermektedir $(79,80)$. $\mathrm{Bu}$ sonuç, sağlık eğitimi alan bireylerin sağlık konularına ilişkin farkındalığının daha yüksek olması ve besin destekleri hakkında daha fazla bilgi sahibi olmaları ile ilişkilendirilmektedir (39).

Araştırmaya katılanlarda algılanan gelir düzeyi ile pandemi sürecinde besin destekleri kullanımı da ilişkilidir $(p<0.05)$. Besin desteği kullanım oranı en düşük olan katılımcılar, gelir düzeyinin 'kötü' olduğunu bildirenlerdir (Tablo 5). Farklı çalışmalarda da gelir düzeyi arttıkça pandemi sürecinde besin destekleri kullanımının arttığ gözlenmiştir Bu sonuç, aynı zamanda bireyin eğitim düzeyi arttıça satın alma gücünün artmasıyla da ilişkilendirilmektedir $(54,62)$.

Dünyadaki ölüm nedenlerinin çoğunluğundan sorumlu olan kronik hastalıklar, beslenmenin düzeltilmesi ile önlenebilmektedir. Günümüzde, hastalıklardan korunmak ve hastalık etkilerini hafifletmek amacıyla vitamin-mineral kullanımı artmıştır. Özellikle vitamin ve minerallerin vücuttaki yaşamsal faaliyetleri nedeniyle vitamin ve mineral içeren besin desteklerinin kullanımı kronik hastalıklarda görülmektedir (35). Çalışmamızda katılımcıların besin desteği kullanımları kronik hastalık öyküsüne göre incelendiğinde; kronik hastalığa sahip olan katılımcıların pandemi sürecinde besin destekleri kullanımının daha yüksek olduğu belirlenmiştir $(\mathrm{p}<0.05$, Tablo 5). Çalışmalarda da genellikle kronik hastalığı olanlarda, vitaminmineral kullanımının daha yaygın olduğu bildirilmiştir $(39,75,81,82)$. Örneğin; bir çalışmada kemik hastalıkları olan katılımcıların vitaminmineral kullanım oranı, hastalığı olmayan katılımcılara göre 1.85 kat daha yüksek bulunmuştur (83). Benzer şekilde başka bir çalışmada da kronik hastalığı bulunan katılımcıların besin destekleri kullanımı daha yüksek bulunmuştur (39). Çalışmamızda COVID-19 tanısı olan hastaların pandemi döneminde besin desteği kullanımı, COVID-19 tanısı olmayanlara göre daha yüksektir ( $\mathrm{p}<0.05$, Tablo 5 ). Bu sonuç, COVID-19 tanısı olan hastaların, besin desteği kullanımının faydalı olduğunu düşünmeleriyle ilişsili olabilir. Başka bir araştırmada da
COVID-19 pozitif olanların, multivitamin kullanımının tanı sonras1 arttığı gösterilmiştir. COVID-19 tanısı alan erkekler, kadınlara göre anlamlı düzeyde yüksek multivitamin ve çinko kullanırken; COVID-19 hastası kadınlar, daha fazla oranda C ve D vitamini kullanmıştır (54). Yetersiz beslenmenin, iyileşmeyi geciktirerek ve hastanede kalış süresini uzatmak suretiyle, COVID-19 hastaları için risk oluşturduğu bu nedenle doğru beslenme müdahalelerin hastaların klinik sonuçlarını iyileştirebileceği bildirilmektedir (84). Çalışmada, COVID-19 tanısı olan katılımcıların besin destekleri kullanmaları olumlu bir bulgu olarak değerlendirilebilir. Bununla birlikte, WHO, bağışıklık sistemi için önemli rolü olan vitamin/minerallerin sağlıklı bireylerde öncelikle meyve, sebze ve hayvansal kaynakları da içeren dengeli ve çeşitli bir diyet ile karşılanabileceğini; pandemi sürecinde takviye olarak tüketilmelerinin COVID-19'u önleyici veya COVID-19 hastalığı olan kişilerde tedavi edici olduğuna dair kanıtların olmadığını bildirmiştir (85).

\section{Sonuç}

Son yıllarda alternatif tedavilerin popüler hale gelmesiyle birlikte besin takviyeleri, fonksiyonel gıdalar ve bitkisel ürünlere olan ilgi artmaya başlamıştır. Bunun yanı sıra; COVID-19 salgınının hızla yayılması, dünya çapında birçok endişeyi de beraberinde getirmiş ve bağışıklığı artırmak, hastalığın bulaşmasını önlemek veya hastalığın seyrini hafifletmek için doğal ürünler ve bitki özlerinin kullanılması gibi alternatif seçeneklere olan talebi arttırmıştır. COVID-19 pandemisi sürecinde yetişkin bireylerin besin destekleri kullanımlarının incelendiği bu araştırmada, dünyada olduğu gibi ülkemizde de pandemi sürecinde besin destekleri kullanımının arttığı ortaya çıkmıştır. Araştırma sonucuna göre, katılımcıların yarıdan fazlasının besin desteklerinin COVID-19'a karşı koruyucu olduğuna inandığı, COVID-19 tanısı olanların çoğunluğunun besin destekleri kullanmaya başladıkları saptanmıştır. Katılımcıların besin desteği hakkında bilgi edinirken kitle iletişim araçlarına başvurduğu, besin desteği kullanma kararında sağlık uzmanlarının, kitle iletişim araçlarının ve yakın çevrenin etkili olduğu belirlenmiştir. Pandemi sürecinde en çok kullanılan besin destekleri C, D, B grubu vitaminleri, zencefil, tarçın, yeşil çay ve zerdeçaldır. Çalışmada ayrıca, besin destekleri kullanımında, cinsiyet, öğrenim durumu ve yaşanılan yer, medeni durum, gelir, meslek, kronik hastalık durumu, COVID-19 tanısı olma durumunun etkili olduğu saptanmıştır.

Günümüzde, sağlık otoriteleri tarafindan COVID-19'un önlenmesi veya COVID-19'un tedavisi için besin takviyesi konusunda bir kılavuz bulunmamakta olup otoriteler tarafından bu süreçte bağışıklık sistemini güçlü tutmak amaciyla günlük diyetle taze sebze, meyve, tahıl, hayvansal kaynaklı besinlerin alınması, hazır ve işlenmiş gıdalardan uzak durulması, şeker ve katı yağ tüketiminin azaltılması, sıv1 tüketiminin artırılması önerilmektedir. Bunun yanı sıra; besin destekleri, beslenmeyi destekleyici veya bağışıklığı güçlendirici olarak kullanılmasına rağmen bireylerin besin destekleri konusunda eksik veya hatalı bilgiye sahip olması, besin desteklerinin kolay erişebilir olması, bilinçsiz kullanım sonucunda sağlığı bozucu etkilere neden olmaktadır. Bu nedenlerle, bireylerin sağlıklı ve doğal beslenmesi, besin desteklerinin ihtiyaç halinde doktor veya diyetisyen gibi uzmanların kontrolünde kullanılması ve sağlığa etkileri konusunda farkındalığın artırılması önemlidir. Toplumda, besin desteklerinin kullanım koşulları, endikasyonları, yan etkileri ve COVID-19 ile olan etkileşimine ilişkin yerel ve ulusal düzeylerde bilinçlendirme çalışmalarının faydalı olacağı düşünülmektedir. 


\section{Çalışmanın Sınırlılıkları}

Araştırmada bazı sınırlılıklar bulunmaktadır. Bunlardan ilki, verilerin pandemi koşulları nedeniyle online olarak ve anket aracılığıyla toplanmasıdır. Bu durum, soruların katılımcı tarafından anlaşılabilirliği ve yanıtların güvenilirliği açısından eksiklik oluşturabilir. İkinci olarak, araştırmanın belirli zaman aralığında ve belirli katılımcı sayısıyla yürütülen kesitsel tipte bir araştırma olması, bulguların genellenebilirliğini sınırlamaktadır. Bununla birlikte, çalışmanın online olarak yürütülmesi, farklı coğrafi bölgelerde yaşayan daha fazla sayıda bireye ulaşma imkânı sağlamış ve veri toplama hızını arttırmıştır.

Sinırlılıklara rağmen elde edilen bulguların toplumun pandemi sürecindeki sağlık davranışlarını ortaya koyması açısından, toplum sağlığının güçlendirilmesi amacıyla yapılacak çalışmalara ön veri sunmaktadır. Bu açıdan bu çalışmanın literatüre katkı sağlayacağı düşünülmektedir.

\section{Kaynaklar}

1.Rothan HA, Byrareddy SN. The epidemiology and pathogenesis of coronaviru disease (COVID-19) outbreak. Journal of autoimmunity 2020;109:102433.

2.Adhikari SP, Meng S, Wu YJ, et al. Epidemiology, causes, clinical manifestation and diagnosis, prevention and control of coronavirus disease (COVID-19) during the early outbreak period: a scoping review. Infectious Diseases of Poverty 2020;9(1):1-12.

3. Shakoor H, Feehan J, Al Dhaheri AS, et al. Immuneboosting role of vitamins D, C, E, zinc, selenium and omega-3 fatty acids: could they help against COVID-19? Maturitas 2021;143:1-9.

4.Jayawardena R, Sooriyaarachchi P, Chourdakis M, Jeewandara C, Ranasinghe P. Enhancing immunity in viral infections, with special emphasis on COVID-19: A review. Diabetes \& Metabolic Syndrome: Clinical Research \& Reviews 2020;14(4):367-82

5.Jawhara S. Could intravenous immunoglobulin collected from recovered coronavirus patients protect against covid-19 and strengthen the immune system of new patients? International Journal of Molecular Sciences 2020;21(7):2272

6.Curtis LJ, Bernier P, Jeejeebhoy K, et al. Costs of hospital malnutrition. Clinica Nutrition 2017;36(5):1391-6.

7.Polamarasetti P, Danik M. Nutrition planning during the covid-19 pandemic for aging immunity. Bioactive Compounds in Health and Disease 2020;3:109-23.

8.Wintergerst ES, Maggini S, Hornig DH. Contribution of selected vitamins and trace elements to immune function. Annals of Nutrition and Metabolism 2007;51(4):301-23

9.Maggini S, Pierre A, Calder PC. Immune function and micronutrient requirements change over the life course. Nutrients 2018;10(10):1531.

10.Calder PC. Nutrition, immunity and covid-19. BMJ Nutr Prev Health 2020;3:e000085:74-92.

11.Martineau AR, Jolliffe DA, Hooper RL, et al. Vitamin D supplementation to prevent acute respiratory tract infections: systematic review and meta-analysis of individual participant data. BMJ 2017;356:i6583.

12.Gombart AF, Pierre A, Maggini S. A review of micronutrients and the immune system-working in harmony to reduce the risk of infection. Nutrients 2020;12:236.

13.T.C. Sağlık Bakanlığı. Türkiye Beslenme ve Sağlık Araştırması (TBSA) 2019 Ankara 2019;69-195.

14.Ergen A, Bekoğlu FB. Türkiye'de besin destek ürünlerine yönelik görüşler ve tüketici profilini tanımlamaya yönelik bir araştırma. İşletme Araştırmaları Dergisi 2016;8(1):323-41.

15.Austin Z, Martin JC, Gregory PA. Pharmacy practice in times of civil crisis: The experience of SARS and the blackout in Ontario, Canada. Res. Social Adm Pharm.
2007;3: 320-35.

16.Lake MA. What we know so far: COVID-19 current clinical knowledge and research. Clin. Med. (Lond.) 2020;20:124-7.

17.World Health Organization, 2020a. 'Modes of transmission of virus causing COVID-19: implications for IPC precaution recommendations'. Available at: https://www.who.int/news-room/commentaries/detail/modes-of-transmission-ofvirus-causing-covid-19-implications-for-ipc-precaution-recommendations. Erişim tarihi 10 Ağustos 2021. (Accessed August 10, 2021.)

18.World Health Organization, 2020b. "Report of the WHO-China Joint Mission on Coronavirus Disease 2019 (COVID-19) ". Available at: https://www.who.int/ publications/i/item/report-of-the-who-china-joint-mission-on-coronavirus-disease2019-(covid-19). Erişim tarihi 8 Ağustos 2021. (Accessed August 8, 2021.)

19.Salathe M, Althaus CL, Neher R, et al. COVID-19 epidemic in Switzerland: on the importance of testing, contact tracing and isolation. Swiss. Med. Wkly 2020;150:w20225.

20.Grebow, J. Dietary supplement sales skyrocket during coronavirus pandemic. Nutritional Outlook 2020;23(4):14.

21.Kantar. Consumer panel for food, beverages and household products, 2020. Available: kantarworldpanel.com. Erişim tarihi 10 Ağustos 2021. (Accessed August 10, 2021.)

22.Adams KK, Baker WL, Sobieraj DM. Myth busters: dietary supplements and COVID-19. Ann. Pharmacother 2020;54:820-6.

23.Çimke S, Yıldırım Gurkan D. Determination of interest in vitamin use during covid-19 pandemic using google trends data: Infodemiology study. Nutrition 2021;85:1-6.

24.Ipsos Araștırma Merkezi. (2021). Koronavirüs salgını ve toplum araștırmasının 49. dönem verileri. Available at: https://www.ipsos.com/tr-tr/vatandaslar-salginbasindan-bu-yana-ortalama-66-kilo-almis. Erişim tarihi 10 Ağustos 2021. (Accessed August 10, 2021.)

25.Del Castillo MD, Iriondo-DeDond A, Martirosyan DM. Are functional foods essential for sustainable health? Ann. Nutr. Food Sci. 2018;2:1015.

26.Ilie PC, Stefanescu S, Smith L. The role of Vitamin D in the prevention of Coronavirus Disease 2019 infection and mortality. Aging Clinical and Experimental Research 2020;32(7):1195-8.

27.Zhang J, Taylor EW, Bennett K, Saad R, Rayman MP. Association between regional selenium status and reported outcome of COVID-19 cases in China [Letter to the editors]. The American Journal of Clinical Nutrition 2020;111(6):1297-9.

28.Hemilä H, Chalker E. Vitamin C may reduce the duration of mechanical ventilation in critically ill patients: a meta-regression analysis. Journal of Intensive Care 2020;8(1):15.

29.Razzaque MS. COVID-19 pandemic: can maintaining optimal zinc balance enhance host resistance? The Tohoku Journal of Experimental Medicine 2020;251(3):175-81.

30.Calder PC, Carr AC, Gombart AF, Eggersdorfer M. Optimal nutritional status for a well-functioning immune system is an important factor to protect against viral infections. Nutrients 2020;12:1181.

31.European Food Safety Authority (EFSA). Tolerable upper intake levels for vitamins and minerals. The EFSA Journal 2006;10:1-45.

32.Al-Naggar AR, Chen R. Prevalence of vitaminmineral supplements use and associated factors among young Malaysians. Asian Pacific Journal of Cancer Prevention 2011;12:1023-9.

33.Buttriss J. Vitamins and minerals. Nutrition \& Food Science 1989;89(1):7-9.

34.Bellikci Koyu E, Karaağaç Y. Viral enfeksiyonlarda vitaminler ve mineraller: covid-19 odağında bir derleme. İzmir Kâtip Çelebi Üniversitesi Sağlık Bilimleri Fakültesi Dergisi 2020;5(2):165-73.

35.Tek NA, Pekcan G. Besin Destekleri Kullanılmalı mı? Hacettepe Üniversitesi, Sağlık Bilimleri Fakültesi, Beslenme ve Diyetetik Bölümü. Ankara: Klasmat Matbaacilık, 2008, 27.

COVID-19 Pandemisi ve Besin Destekleri Kullanımı - Demir ve ark. 
36.Kamarli Altun H, Karacil Ermumcu MS, Seremet Kurklu N. Evaluation of dietary supplement, functional food and herbal medicine use by dietitians during the COVID-19 pandemic. Public Health Nutrition 2020;24(5):861-9.

37.AlGaeed H, Aljaber M, Alwehaibi, A, et al. General public knowledge and use of dietary supplements in Riyadh, Saudi Arabia. J. Fam. Med. Prim. Care 2019;8:3147.

38.Samreen S, Siddiqui AN, Wajid S, Mothana AR, Almarfadi OM. Prevalence and use of dietary supplements among pharmacy students in Saudi Arabia. Risk Manag. Healthcare Polic 2020,13:1523-31.

39.Bellikci Koyu E, Çalık G, Kaner Tohtak G, Günsel Yıldırım G. Sağlık çalışanlarının besin desteği kullanma durumları ve ilişkili etmenler. Dokuz Eylül Üniversitesi Tıp Fakültesi Dergisi 2020;34(2):141-51

40.Faul F, Erdfelder E, Lang AG, Buchnre A. G*Power 3: A flexible statistica power analysis program for the social, behavioral, and biomedical sciences. Behavior Research Methods 2007;39(2):175-91.

41.Bakan Koçak S. Çankırı özel Karatekin hastanesi sağlık personeli ve diye polikliniğine başvuran hastalarda gıda takviyelerinin kullanımı üzerine bir araștırma. Yüksek Lisans Tezi. Gazi Üniversitesi/Sağlık Bilimleri Enstitüsü, Ankara, 2013.

42.Kafadar D, Sayın E, Çelik İH. Aile hekimliği polikliniğine başvuran hastaların vitamin / mineral destekleri ile ilgili bilgi ve tutumları. Jour Turk Fam Phy 2020;11(2):56-67.

43.Karadeniz S. Beslenme ve diyetetik polikliniğine başvuran hastaların, bitkisel ürün ve besin destekleri hakkındaki bilgi ve tutumlarının saptanması. Yüksek Lisans Tezi. Yeditepe Üniversitesi/Sağl1k Bilimleri Enstitüsü, İstanbul, 2020.

44.Sirico F, Miressi S, Castaldo C, et al. Habits and beliefs related to food supplements: results of a survey among Italian students of different education fields and levels. Plos One 2018;13(1):e0191424

45.Özcan V. İlaç ve gıda takviyelerinin içerikleri hakkında kullanıcıların bilgi ve talep düzeyinin ölçülmesi. Yüksek Lisans Tezi. İstanbul Medipol Üniversitesi/ Sağlık Bilimleri Enstitüsü, İstanbul, 2018.

46.Özkan S. Zayıflama amaçlı kullanılan bitkisel besin desteklerinin tüketim sıklığ ve etkinliği. Yüksek Lisans Tezi. İstanbul Okan Üniversitesi/Sağlik Bilimleri Enstitüsü, İstanbul, 2019.

47.Available at: https:/www.euro.who.int/en/health-topics/disease-prevention nutrition/a-healthy-lifestyle/body-mass-index-bmi. Erişim tarihi 7 Ekim 2021 (Accessed October 7, 2021.)

48.Hayran, O., Özbek, H. Sağlık Bilimlerinde Araştırma ve İstatistik Yöntemler İstanbul: Nobel Tip Kitapevi, 2017.

49.Haleem A, Javaid M, Vaishya R. Effects of COVID 19 pandemic in daily life Current Medicine Research and Practice Curr Med Res Pract. 2020;10(2):78-9.

50.Muscogiuri G, Barrea L, Savastano S, Colao A. Nutritional recommendations for COVID-19 quarantine. Eur J Clin Nutr. 2020;74:850-1.

51.Coelho-Ravagnani CF, Corgosinho FC, Sanches FFZ, et al. Dietary recommendations during the COVID-19 pandemic. Nutr Rev. 2020;0(0):1-14.

52.Brooks SK, Webster RK, Smith LE, et al. The psychological impact of quarantine and how to reduce it: Rapid review of the evidence. Lancet 2020;395:912-20.

53.Demir, G. Nutrition, health behaviour changes, and eating behaviours of adults during the covid 19 pandemic period. TJFM\&PC 2020;14(4):639-45.

54.Alwafaz HA, Khan N, Aljumah GA, Hussain SD, Al- Daghri NM. Dietary intake and supplement use among Saudi residents. Environ. Res. Public Health 2021;18:6435

55.Scarmozzino F, Visioli F. Covid-19 and the subsequent lockdown modified dietary habits of almost half the population in an Italian sample. Foods 2020;9(5):675.

56.Liu J, Liao X, Qian S, et al. 2020. Community transmission of severe acute respiratory syndrome coronavirus 2, Shenzhen, China, 2020. Emerg. Infect. Dis. 2020;26:1320-3

57.Hathcock J. Dietary supplements: how they are used and regulated. J Nutr 2001;131:1114-7.
58.Euromonitor International. Dietary Supplements in Poland 2020. Available at: https://www.euromonitor.com/dietary-supplements-in-poland/report. Erişim tarihi 10 Ağustos 2021. (Accessed August 10, 2021.)

59.Alyami HS, Orabi MAA, Aldhabbah FM, et al. Knowledge about covid-19 and beliefs about and use of herbal products during the covid-19 pandemic: a crosssectional study in Saudi Arabia. Saudi Pharmaceutical Journal 2020;28:1326-32.

60.Zhao A, Li Z, Ke Y, et al. Dietary diversity among Chinese residents during the covid-19 outbreak and its associated factors. Nutrients 2020;12(6):1699.

61.Lam CS, Koon HK, Chung VCH, Cheung YT. A public survey of traditional, complementary and integrative medicine use during the COVID-19 outbreak in Hong Kong. Plos One 2021;16(7):e0253890.

62.Mestaghanmi H, Labriji A, Kehailou FZ, et al. Study of the association between the consumption of dietary supplements and lifestyle factors in a population of Moroccan academics during the covid 19 health crisis. Open Access Library Journal 2021;8:e7585.

63.Hamulka J, Jeruszka-Bielak M, Górnicka M, Drywień ME, Zielinska-Pukos MA. Dietary Supplements during COVID-19 outbreak. Results of Google Trends analysis supported by PLifeCOVID-19 online studies. Nutrients 2021;13(1):54.

64.Samar E. Pandemi sürecinde spor salonlarında egzersiz yapan kişilerde gıda takviyesi kullanma durumunun incelenmesi. ISPEC Journal of Social Sciences \& Humanities 2021;5(2):189-203.

65.Kılıç Kanak E, Öztürk SN, Özdemir Y, Asan K, Öztürk Yılmaz S. Gıda takviyeleri kullanım alıskanlıklarının değerlendirilmesi. Niğde Ömer Halisdemir Üniversitesi Mühendislik Bilimleri Dergisi 2021;10(1):168-77.

66.Kutlu N, Ekin MM, Alav A, Ceylan Z, Meral R. Covid-19 pandemi sürecinde bireylerin beslenme alışkanlığında meydana gelen değişimin belirlenmesi üzerine bir arastırma. International Journal of Social, Political and Economic Research 2021;8(1):173-87.

67.EL Alamlab A, Fattah A, Chait A. Medicinal plants used for the prevention purposes during the covid-19 pandemic in Morocco. J. Analytical Sci. Appl. Biotechnol 2020;2:4-11.

68.Chen F, Du M, Blumberg JB, et al. Association among dietary supplement use, nutrient intake, and mortality among U.S. adults: a cohort study. Ann Intern Med 2019;170(9):604-13.

69. Kofoed CLF, Christensen J, Dragsted LO, Tjønneland A, Roswall N. Determinants of dietary supplement use-healthy individuals use dietary supplements. Br J Nutr. 2015;113:1993-2000.

70.Pouchieu C, Andreeva VA, Peneau S, et al. Sociodemographic, lifestyle and dietary correlates of dietary supplement use in a large sample of French adults: results from the NutriNet-Sante Cohort Study. Br J Nutr. 2013;110:1480-91.

71.Dickinson A, Blatman J, El-Dash N, Franco JC. Consumer usage and reasons for using dietary supplements: report of series of surveys. J Am Coll Nutr 2014;33(2):176-82.

72.Marupuru S, Axon DR, Slack MK. How do pharmacists use and recommend vitamins, minerals, herbals and other dietary supplements? BMC Complement Altern Med. 2019;19:229.

73.CRN-Funded COVID-19 Survey. Available at: https://www.statista.com/ statistics/1180357/dietary-supplement-usagechange-due-to-covidus-adults-bygender/. Erişism tarihi 8 Ağustos 2021. (Accessed August 8, 2021.)

74.Friis K, Lasgaard M, Rowlands G, Osborne RH, Maindal HT. Health literacy mediates the relationship between educational attainment and health behavior: a Danish population-based study. J Health Commun 2016;21(sup2):54-60.

75.Rovira MA, Grau M, Castañer O, et al. Dietary supplement use and healthrelated behaviors in a mediterranean population. Journal of nutrition education and behavior 2013; 45(5):386-91.

76.Alfawaz H, Khan N, Alfaifi A, et al. Prevalence of dietary supplement use and associated factors among female college students in Saudi Arabia. BMC Women's Health 2017;17:1-7.

77.O'Brien SK, Malacova E, Sherriff JL, Black LJ. The prevalence and predictors of dietary supplement use in the Australian population. Nutrients 2017;9:1154. 
78.Kim JW, Lee SH, Kim JE, et al. The association between taking dietary supplements and healthy habits among Korean adults: results from the fifth Korea National Health and Nutritional Examination Survey (2010-2012). Korean J Fam Med. 2016;37:182-7.

79.Kim HJ, Giovannucci E, Rosner B, Willett WC, Cho E. Longitudinal and secular trends in dietary supplement use: nurses' health study and health professionals follow-up study, 1986-2006. J Acad Nutr Diet. 2014;114:436-43.

80.Kobayashi E, Sato Y, Umegaki K, Chiba T. The prevalence of dietary supplement use among college students: a nationwide survey in Japan. Nutrients 2017;9:1250.

81.Li K, Kaaks R, Linseisen J, Rohrmann S. Consistency of vitamin and/or mineral supplement use and demographic, lifestyle and health-status predictors: findings from the European Prospective Investigation into Cancer and Nutrition (EPIC)Heidelberg cohort. Br J Nutr. 2010;104:1058-64.

82.Marques-Vidal P, Vollenweider P, Waeber G. Trends in vitamin, mineral and dietary supplement use in Switzerland. The CoLaus study. Eur J Clin Nutr. 2017;71:122-7.

83.Lee JS, Kim J. Factors affecting the use of dietary supplements by Korean adults: data from the Korean National Health and Nutrition Examination Survey III. Journal of the American Dietetic Association 2009;109(9):1599-1605.

84.Brugliera L, Spina A, Castellazzi P, et al. Nutritional management of covid-19 patients in a rehabilitation unit. Eur. J. Clin. Nutr. 2020;74:860-3.

85.World Health Organization, 2020. Coronavirus disease (COVID-19): Food safety and nutrition. Available at: https://www.who.int/news-room/q-a-detail/ coronavirus-disease-covid-19-food-safety-and-nutrition. Erişim tarihi 7 Ekim 2021. (Accessed October 7, 2021.) 